\title{
LIBERAL THINKING IN SALAF PESANTREN, IS IT POSSIBLE? (FREEDOM OF THOUGHT THE SANTRI MA'HAD ALY SUKOREJO, SITUBONDO)
}

\author{
Marjuni1a, Moch. Khafidz Fuad Raya ${ }^{2 b}$ \\ 1Institut Agama Islam Riyadlotul Mujahidin Ngabar Ponorogo, Indonesia \\ 2Institut Agama Islam Darullughah Wadda'wah Pasuruan, Indonesia \\ amarjuniwsngabar@gmail.com, bhafidzraya@yahoo.co.id
}

\begin{abstract}
The existence of Ma'had 'Aly is an exciting thing and brings a narrative of controversy. Since being legalised in 2002, Ma'had 'Aly has transformed into a modern Islamic educational institution under the auspices of a traditional Salaf pesantren. This article aims to explain Ma'had 'Aly as an Islamic educational institution that specifically (takhasșus) produces fiqh experts and supports freedom of thought in exploring Islamic law. The research method uses a qualitative approach by studying documents extracted from the history of Ma'had 'Aly, the takhașus curriculum, and the Tanwirul Afkar (TA) bulletin. The results reveal the integration of the Ma'had 'Aly curriculum, which is combined with the general curriculum and contemporary scriptures. Second, the controversy over TA as a forum for students to manifest their competence as fuqaha on various developing issues. Some of the controversial issues decided by TA were allowing interfaith marriages, allowing non-Muslim Indonesian President elections, and similarities between Islam and Christianity in relations and history. Some realities above show that Islamic liberal thought has emerged in salaf pesantren through Ma'had 'Aly. The contribution of this research provides novelty that apparently Ma'had 'Aly is trying to show that the door of $i j t i h \bar{a} d$ in the excavation of Islamic jurisprudence is still wide open.
\end{abstract}

Keywords: pesantren, freedom of thought, Islamic jurisprudence, liberal, tanwirul afkar.

\section{INTRODUCTION}

The study of pesantren has been well established and discussed by many researchers from various perspectives. The existence of pesantren was detected in the 13th century, where a small pesantren was founded by Sheikh Maulana Malik al-Maghribi in East Java before the emergence of Wali Songo (Raya, 2018). In the modern context, pesantren is considered a backward educational institution that only focuses on studying classical texts called the yellow book as a source of Islamic law (Bruinessen, 1995; van Bruinessen, 
Marjuni, M. Raya, M.F. (2021). LIBERAL THINKING IN SALAF PESANTREN, IS IT POSSIBLE? (FREEDOM OF THOUGHT THE SANTRI MA'HAD ALY SUKOREJO, SITUBONDO). Jurnal Tatsqif, 19 (2), 175-191. https://doi.org/10.20414/jtq.v19i2.4307

1990). Besides that, the appearance of santri wearing sarongs which are used in various daily activities as a sign that this institution is very traditional, so it is not surprising that santri are popularly called 'kaum sarungan' (Ja'far, 2013). However, according to some observers, it is these elements that make pesantren unique and indigenous that have deep roots in Indonesian society (Bruinessen, 1995; Dhofier, 1994; Lukens-Bull, 2019).

As the oldest Islamic educational institution and adheres to a traditional system, pesantren is also known as a conservative institution that limits thinking to all elements of the pesantren. The reasoning is to avoid thinking that is radical and not by the advice of the 'ulamā'. This reason is also the basic principle adopted by pesantren that the door of jihad has been closed, or what is called qafl bāb al-ijtihād. These two reasons were strengthened by the emergence of radical thoughts from pesantren precisely at the Pesantren Al-Islam Lamongan gave birth to graduates who were members of the terrorist circle in the Bali Bombings I and II (Hefner, 2009). Other such as Pesantren Ngruki Solo Central Java, which proclaimed itself not to recognise Pancasila as the ideology and basis of the Indonesian state, are considered țaghūt (idols, everything that is contrary to God) (Hikmatulloh, 2007). Seeing the pesantren that gave birth to a radical image, after the Bali Bombing II Jusuf Kalla as Vice President of Indonesia ordered supervision for pesantren. This step was quite controversial and there was a wave of protests from moderate Islamic boarding schools because they were interventionist against pesantren, which had existed as independent institutions as Dasuki did in his dissertation at McGill University (Dasuki, 1974).

This fear is quite reasonable because in pesantren the textual tradition is highly respected for the reason of maintaining scientific continuity. The motif for acts of terrorism is because the perspective of interpreting the Qur'ān on several topics is not tolerated by its adherents. Like the language of al-Qitāl in its meaning, it means jihad or holy war to uphold religion. In this segment, terrorists are prohibited from thinking independently in interpreting the 
Qur'ān based on interpreting other classical texts, such as what Abu Bakar Ba'asyir taught to students studying at the Pesantren Ngruki Solo. On a certain side, the pesantren displays its 'exclusive' figure for the sake of purification of knowledge, as in the discussion of aqidah and sharia.

Many people assume pesantren is expected to become an Islamic educational institution that maintains the identity of its traditional system (Hidayah, 2021; Ihsan \& Fatah, 2021; Isbah, 2020a; Manshur, 2020). However, seeing the phenomenon of Ma'had 'Aly as a "pilot project" for making fuqaha differs in principles in several ways, especially the thoughts and movements of Ma'had 'Aly's first embryo in Situbondo.

Against this substantive phenomenon, this article examines freedom of thought as an educational program implemented by pesantren. We found a new form called Ma'had 'Aly in Situbondo as the first institution in Indonesia to use this form. Ma'had 'Aly focused on the freedom of thought of the students to study Islamic laws. Ma'had 'Aly's discussion was about curriculum, learning methods, journals, or weekly bulletins called Tanwirul Afkar (TA). This article examines what is not discussed by Zarkasyi, where freedom of thought in emerges from the modern pesantren model, such as in the Pesantren Gontor Ponorogo, East Java (Zarkasyi, 2020). This research is a manifestation of the embryo of moderatism in pesantren that have accepted freedom of thought for the pesantren community studied by Ni'am (2015). This research is unique because Ma'had 'Aly is affiliated with a salaf pesantren (Pesantren Salafiyah Syafi'iyah Sukorejo, Situbondo) which is not discussed in Zarkasyi and Ni'am's research. This research provides a novelty as a new pattern of traditional pesantren which has been transformed into an inclusive institution in freedom of thought which has been opposed by traditional principles, providing certainty that liberal thinking in salaf pesantren has occurred. 


\section{METHODS}

This research uses a qualitative approach with the document study method (Aspers \& Corte, 2019; Salminen dkk., 1997). Because of the documents studied classified as a literature study. The documents excavated are from the history of the establishment of Ma'had 'Aly Situbondo which was the first in Indonesia. The second document of the takhașsus curriculum, which lists various traditional fiqh books and contemporary books and the lecturers who teach at Ma'had 'Aly. The next document is the bulletin Tanwirul Afkar (TA) which contains controversial editions on three topics: interfaith marriage, non-Muslim presidents, and the similarities between Islam and Christianity in relations and history. The documents were analysed using the document triangulation technique (Natow, 2020), where the history of Ma'had 'Aly as a takhașsuș institution was codified with an integrated curriculum and TA bulletins.

\section{RESULT AND DISCUSSION}

\section{Traditional Characteristics of Pesantren}

The development of pesantren is currently approaching the direction of progress. This indicator can be seen in data released by the Directorate of Diniyah and Pesantren, 33,218 pesantren with 72 Ma'had 'Alys spread throughout Indonesia in 2021 (Ditpontren Kemenag RI, 2021). The existing pesantren are not only owned by the traditionalists, the modernists also build pesantren as their group's existence to take the opportunities of the times. Even though there are modern pesantren, but overall they still apply the classical system by learning the "kitab kuning or yellow book" as said by Martin van Bruinessen (van Bruinessen, 1990).

In the pesantren tradition (both salaf and modern), the truth of the yellow book is absolute and indisputable knowledge, the criticism of the book is only limited to commenting on it which is called sharh (Abdullah, 2020). All truths in the yellow book are final and cannot be changed by anyone and 
Marjuni, M. Raya, M.F. (2021). LIBERAL THINKING IN SALAF PESANTREN, IS IT POSSIBLE? (FREEDOM OF THOUGHT THE SANTRI MA'HAD ALY SUKOREJO, SITUBONDO). Jurnal Tatsqif, 19 (2), 175-191. https://doi.org/10.20414/jtq.v19i2.4307

under any conditions. There have been every effort made by the 'ulamā' to reinterpret the meaning of the yellow book text, but not a few have received protests and criticism from the 'ulamā' who want to maintain the purity of the sacred text written by the 'ulamā' as well. This also applies to texts that narrate radical meanings on certain themes, but interpretation and reinterpretation of various arguments from other texts as comparisons are sometimes not accepted.

Although they both apply traditional systems, modern pesantren are more critical of the yellow book and prefer a direct interpretation of the Qur'ān and Hadīth as the main and first sources in Islam. Latif Fauzi's findings are quite reasonable, the debate is because of the cultural confrontation between traditionalists and modernists which causes the polarisation of the role kyai as the leader of pesantren as a determinant of the traditional pattern of pesantren (Fauzi, 2012). Modernists have publicly stated that the gates of ijtihād are still wide open with freedom of thought. Traditionalists claim that the door of $i j t i h \bar{a} d$ for interpreting classical texts is closed and undeniable, like the Qur'ān and Ḥadīth.

Kyai is a central element in the implementation's spearhead of the pesantren. This institution is the kyai's media in expanding da'wah and its influence on the community. Kyai, as the owner institution and the centre of power, this role affects the direction of pesantren education. The other two elements, such as lodging and mosques, characterise the setting of the pesantren as a full day educational institution where students fully study Islam and interact with teachers and worship in one area. In reality, the kyai's house is in a pesantren complex which is next to the boarding school for santri to make it easier to control the implementation of education.

Another uniqueness of the method and its application in learning. Pesantren learning methods are very typical, one of which is often used is Sorogan and Bandongan. Dhofier and Nurtawab said it was a method where the kyai recited the yellow book in the mosque or in an open space, while the 
Marjuni, M. Raya, M.F. (2021). LIBERAL THINKING IN SALAF PESANTREN, IS IT POSSIBLE? (FREEDOM OF THOUGHT THE SANTRI MA'HAD ALY SUKOREJO, SITUBONDO). Jurnal Tatsqif, 19 (2), 175-191. https://doi.org/10.20414/jtq.v19i2.4307

santri listened and listened to the kyai's explanation. Derived from the Sundanese word 'ngabandungan' which means flocking. The students who attend do not depend on the level of ability and age, and do not recognise the boundaries of the class hierarchy (Dhofier, 1990; Nurtawab, 2019). While sorogan is a mastery method where students must reread the material that has been delivered by the kyai, and students may not move or jump to the next discussion if they have not mastered the material well (Fadli dkk., 2021).

According to the observations of academics, it is stated that pesantren is a traditional Islamic educational institution that is difficult to change. Pesantren firmly maintains the traditional system as part of an effort to maintain a way of transferring knowledge that has been carried out from generation to generation. In addition, the community considers that the yellow book was written by 'ulamā' results from serious excavations accompanied by religious rituals which they believe to be opening the door of guidance such as purification ( $w u d u^{\prime}$ ), fasting, wirid, avoiding evil deeds, and performing tahajjud prayers. Although this assumption is correct, pesantren is open in accommodating local cultural adoption. This then characterises the pesantren as a moderate educational institution and is tolerant of local wisdom. These characteristics make pesantren a typical Indonesian Islamic educational institution.

From the developments that occur, there are three forms of pesantren patterns. First, traditional pesantren which maintain traditional principles, traditions and values with no striking innovations. Second, post-traditional pesantren are a welcome form of developing modern system innovations, but these pesantren still hold firmly to teaching traditional systems. Third, modern pesantren where all the management uses a system that is run in a modern way, both technology, facilities, and the curriculum adopting general sciences as an additional reinforcement of the traditional curriculum. This third pattern of Islamic boarding schools still uses the yellow book as the primary source in exploring and instilling Islamic teachings to students. The 
first pattern is popularly known as 'pesantren salaf' which adopts the word salaf as a sign of traditional identity (salafiyah). While the third pattern is more popular with modern pesantren (Isbah, 2020b).

Referring to the pattern above, the Salafiyah Syafi'iyah Sukorejo pesantren in Situbondo, East Java, built a traditional pesantren tradition. The word 'salafiyah' describes the strong salaf identity in this pesantren. However, several educational institutions under it, such as Ma'had 'Aly and Ibrahimy University, have adopted the modern system as a response to the needs of the times of education. So it can be said that the pesantren still adhere to the traditional system, while Ma'had 'Aly as the corpus of this article also adopts the modern system. This pattern is explained by Alamsyah, where post-traditionalism makes the salaf tradition its fundamental epistemology to transform into an educational institution that is transformed to modern in terms of axiology (Alamsyah, 2017). With the meaning that Ma'had 'Aly's position as a reinforcement of the Salafiyah Syafi'iyah Sukorejo pesantren in maintaining its identity as a traditional institution.

\section{The Foundation of Freedom Thought at Ma'had 'Aly Sukorejo}

As mentioned above, Ma'had 'Aly is one institution under the Salafiyah Syafi'iyah Sukorejo with a specificity of learning (takhașșuș) in fiqh. Students who enter this institution go through a rigorous selection process because the goal is to produce scholars from experts in fiqh more than students who study at pesantren. The word "Ma'had 'Aly" means "the highest institution" in the education system. The existence of this institution was born when the founder of the pesantren (KH. As'ad) saw a shortage of graduates who were experts in fiqh. The establishment of this institution was controversial because the existence of pesantren was not enough to make students experts at fiqh, Why should they create religious institutions within the institution?. 
Marjuni, M. Raya, M.F. (2021). LIBERAL THINKING IN SALAF PESANTREN, IS IT POSSIBLE? (FREEDOM OF THOUGHT THE SANTRI MA'HAD ALY SUKOREJO, SITUBONDO). Jurnal Tatsqif, 19 (2), 175-191. https://doi.org/10.20414/jtq.v19i2.4307

In Ma'had 'Aly the use of fiqh to prepare prospective undergraduates to solve problems in society. It is common in pesantren to use fiqh using one madhab and not switch to another madhab. The popular madhab used is usually Syafi'i and the use of one madhab is a unique style for each pesantren. Madhab Syafi'i has always been associated with pesantren affiliated with the Islamic organisation Nahdlatul 'Ulama (NU) (Arifianto, 2021). Usually in Ma'had 'Aly, the references to the classic yellow book text are not fixed on one madhab. The book that is used as the basis of Islamic jurisprudence is the book of al-Fiqh 'alā Madhāhib al-Arba'ah namely the book of fiqh based on the opinions of the Four Madhabs as material to expand the understanding of students. From the use of this book, Ma'had 'Aly highly respects tolerance in thinking and using Islamic law, not like most pesantren which 'kekeh' maintain their madhab and consider other madhabs as mistakes. This principle is based on the words of the Prophet: "ikhtilāf al-a'immat rahmah" that the differences that occur to Muslims are mercy. Because fiqh is the axis of the lifestyle of the Muslim community in Indonesia according to Bruinessen (van Bruinessen, 1990), its existence is very central to the scientific tradition of pesantren. The resolution of the problems studied revolved around two major themes, namely the problem of worship ('ubūdiyyah) and social intercourse (mu'amalah) so that the problem of differences in beliefs and thoughts was not tolerated to be studied.

Ma'had 'Aly is a unique institution where learning resources are not limited to classical texts. In the library, non-religious books such as science, philosophy, psychology, sociology, anthropology, and others are available. The existence of these books is a sign that Ma'had Aly is trying to find a new formulation of Islamic law to make him rich. In classical fiqh books, contemporary issues and the complexities of societal problems are not discussed and mentioned comprehensively. The Tanwirul Afkar bulletin is an example of the thoughts of Ma'had A'ly students in expressing their freedom of thought that expands fiqh to wider social domains such as science, ecology, 
Marjuni, M. Raya, M.F. (2021). LIBERAL THINKING IN SALAF PESANTREN, IS IT POSSIBLE? (FREEDOM OF THOUGHT THE SANTRI MA'HAD ALY SUKOREJO, SITUBONDO). Jurnal Tatsqif, 19 (2), 175-191. https://doi.org/10.20414/jtq.v19i2.4307

gender, and human rights issues. The uniqueness of Ma'had 'Aly was later endorsed by Prof. Dr. Said Agil Husin al-Munawar as Minister of Religion of the Republic of Indonesia as an equality institution and the graduate received an M.H.I (Masters in Islamic Law) degree, which made him a modern educational institution operating within traditional educational institutions.

\section{Ma'had 'Aly Sukorejo Curriculum: Reference for Freedom of Thought}

As mentioned above, Ma'had 'Aly's focus is on learning fiqh with in-depth and comprehensive studies. So the courses taught are about comparative fiqh, knowledge of the Qur'ān (such as 'Ulūm al-Qur'ān, Tafsīr al-Aḥkām, 'Ulüm al-Hadīth, and others), the science of the Four Madhabs (such as Madhāhib al-Fiqh, al-Masā'il Fiqhiyah volume I and II), Sociology of Islamic Law (such as Muqāranat Qawā'id al-Aḥkām). Other subjects such as History of Islamic Civilization with several volumes, Contemporary Islamic Thought, Islamic Philosophy. To broaden students' understanding, Ma'had 'Aly gave courses on Islamic Civilization in the West, Methodology of Islamic Studies and Research.

Tabel 1. Books of Takhașșuș Fiqh in Ma'had 'Aly

\begin{tabular}{|c|c|c|}
\hline No & Field of Science & Books or Kitab \\
\hline 1 & Fiqh & $\begin{array}{l}\text { Fath al-Mu'în, Minhaj al-Tāāibīn, Tahrīr Tanqīh al-Lubab, } \\
\text { I'ānat al- Țālibīn, Fath̆ al-Wahhāb, al-Madhāhib al-Arba'ah, } \\
\text { Bidāyat al-Mujtahid, Nihāyat al-Muhtaj, al-Muhadhdhab. }\end{array}$ \\
\hline 2 & Ușūl Fiqh & $\begin{array}{l}\text { al-Fikr al- Ușūlỳ, 'Ilm Ușūl al-Fiqh, Jam'ul Jawāmi, Ușūl al- } \\
\text { Aḥkām, al-Risalah, Rawḍat al-Nāzirwa Jannat al-Munāzir, } \\
\text { Ușūl al-Fiqh al-Islamy, al-Mahșul fì ‘Ilm al-Ușūl, al-Irshād } \\
\text { al-Fukhūl, al-Iḥkām fì al-Ușūl lil ‘Āmidy, al-Mustașfāmin } \\
\text { 'Ilm al-Ușūl, al-Muwāfaqāt fị Ușūl al-Aḥām. }\end{array}$ \\
\hline 3 & Qawā'id al-Fiqh & 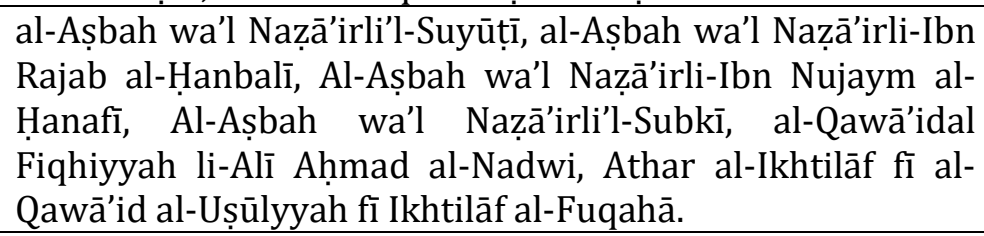 \\
\hline 4 & Tafsir & $\begin{array}{l}\text { Tafsīr al-Ahkām, Rawā'i' al-Bayān, Ahkām al-Qur'ān li'l al- } \\
\text { Jașsāș, Aḥām al-Qur'ān li-Ibn 'Arabi, al-Marāghi, al-Jāmi' } \\
\text { li-Ạhkām al-Qur'ān, Tafsīr Ibn Kathīr, dan lain-lain }\end{array}$ \\
\hline 5 & Ḥadīth & $\begin{array}{l}\text { 'Ulūm al-Hadīth, al-Bukhāri, Hadīth Ahkām, Fath al-Bārī, } \\
\text { Alfiyah li'l Suyūți, dan lain-lain }\end{array}$ \\
\hline
\end{tabular}


Marjuni, M. Raya, M.F. (2021). LIBERAL THINKING IN SALAF PESANTREN, IS IT POSSIBLE? (FREEDOM OF THOUGHT THE SANTRI MA'HAD ALY SUKOREJO, SITUBONDO). Jurnal Tatsqif, 19 (2), 175-191. https://doi.org/10.20414/jtq.v19i2.4307

\begin{tabular}{|c|l|l|}
\hline No & Field of Science & \multicolumn{1}{|c|}{ Books or Kitab } \\
\hline 6 & Sufism & $\begin{array}{l}\text { Minhāj al-'Ābidīn, Ihyā' 'Ulūm al-Dīn, al-Risālah al- } \\
\text { Qushayriyah, dan lain-lain. }\end{array}$ \\
\hline 7 & Akidah & Al-Ibānah 'an Ușūl al-Diyānah, Ușūl al-Dīn. \\
\hline 8 & Islam History & $\begin{array}{l}\text { Tārīkh al-Tashrī' al-Islāmī, Tārīkh al-Tamaddun al-Islāmī, } \\
\text { Tārīkh al-Khulafā', dan lain-lain. }\end{array}$ \\
\hline
\end{tabular}

Lecturers of Ma'had 'Aly are also required to have broad insight, not only understanding religion but also social issues that are not discussed in the pesantren. Lecturers at this institution comprise four categories. First, permanent lecturers or mushrif; These lecturers have to be 'standby' at the institution and they are selected teachers from the best graduates of Ma'had 'Aly. Second, weekly lecturers who give lectures once a week with an emphasis on selected books. Third, monthly lecturers who give lectures once a month emphasise developing social issues so that students can study them in lectures and their final assignments. Fourth, guest lecturers-called almashāyikh, usually teach once a year to provide additional understanding to mahasantri. Usually, the lecturer of Ma'had 'Aly will advise students to refer to these books in writing their paper or final project (thesis). Most times, lecturer Ma'had 'Aly asked the students to discuss the books in class.

With this curriculum, Ma'had 'Aly students can interpret the primary sources of Islamic law (al-Qur'ān and Hadīth) o create new fiqh formulas based on their ijtihād on developing phenomena and issues. In addition, mahasantri also has a broad understanding of the classical texts of the yellow book that they read so that they are not trapped in a blind understanding (taqlid) $\mathrm{f}$ one view. Contextualisation of their interpretation is a step toward freedom of thought. Of course, this can be done if the student has a deep and comprehensive understanding of the study of fiqh.

\section{Tanwirul Afkar Bulletin and Expression of Islamic Liberal Thought}

With the decline of the legality of Ma'had 'Aly in the legislation, this institution has made it confident to step foot to express freedom of thought. 
Marjuni, M. Raya, M.F. (2021). LIBERAL THINKING IN SALAF PESANTREN, IS IT POSSIBLE? (FREEDOM OF THOUGHT THE SANTRI MA'HAD ALY SUKOREJO, SITUBONDO). Jurnal Tatsqif, 19 (2), 175-191. https://doi.org/10.20414/jtq.v19i2.4307

The primary goal is not to criticise classical sacred texts, but to produce fiqh experts (fuqaha). The existence of Ma'had 'Aly further emphasises that the door of ijtihād is still wide open for anyone who wants to "pick up" the moment. Rigidity in the scientific tradition in pesantren so far seems to have "castrated" Muslims to give birth to a monumental work in the history of Islamic civilization. Ma'had 'Aly solves embody the potential of Muslims who are increasingly qualified.

To make this happen, Ma'had 'Aly Sukorejo created a weekly bulletin as a forum for the expression of the students expressing their knowledge in fiqh. Tanwirul Afkar (TA) is a bulletin containing phenomena and issues that develop in society which are described and elaborated by the science of fiqh. TA tries to present factual issues that are always discussed every week and proposes fiqh as an approach to solving problems in these issues. In this sub, we describe the issues discussed by TA and how students express their knowledge as agents freedom of thought.

\section{Interfaith Marriage is Allowed}

This issue is very controversial where many cases occur between Javanese Muslims who work in Bali and marry Hindus. In the texts of classical books, there is no prohibition against interfaith marriage, because in the Qur'ān according to some 'ulamā' the prohibition has been explained. However, Ma'had 'Aly has a different view where it is permissible to marry a non-Muslim, which is taken from the opinion of Yusuf Qardawy. According to him, the prohibition of interfaith marriage is a historical product that is not the same as contemporary conditions. In the past, Prophet Muhammad PBUH prohibited interfaith marriages because they could weaken faith and turn to apostasy, besides fighting the hegemony of Arab infidels who wanted to destroy Islam. Meanwhile, the current situation is different, where Muslims marry non-Muslims to build cooperation, love each other, and even strengthen each other's religion. The decision made by Ma'had 'Aly was 
Marjuni, M. Raya, M.F. (2021). LIBERAL THINKING IN SALAF PESANTREN, IS IT POSSIBLE? (FREEDOM OF THOUGHT THE SANTRI MA'HAD ALY SUKOREJO, SITUBONDO). Jurnal Tatsqif, 19 (2), 175-191. https://doi.org/10.20414/jtq.v19i2.4307

controversial and had invited contra from various parties, especially from the NU community.

\section{Allowing Non-Muslims to be President of the Republic of Indonesia}

The most controversial thing after interfaith marriage is the nomination of the President Republic of Indonesia from non-Muslims. This decision drew the most criticism because it influenced religious politics, which so far the president of Indonesia is a Muslim. Ma'had 'Aly criticised the classical texts in terms of the criteria for a country's leader to be Muslim, but that is for an Islamic country, while Indonesia is a country with various religions, ethnicities, and cultures. The criticism raised about the figure of Prophet Muhammad PBUH as a religious leader and a head of state, so Islam has an integrative concept in leadership where there is no separation between religion and the state. TA emphasised that if this happened, Muslim authorities would discriminate against other religions recognised by the Indonesian state.

\section{Similarities between Islam and Christianity}

The controversy does not stop in the sphere of marriage and politics, but also concerns the relationship between Islam and other religions. If it is related to mu'amalah, some parties may still understand, but this theme is studied from the perspective of fiqh so that it raises protests from various parties. In classical literature that there is no religion other than Islam, and if there is anything related to unbelievers, then it must be Islamized. Some 'ulamā' have agreed that Islam is the last religion to justify and perfect the previous religions that have been perverted like Christianity. Therefore, Islam came to abolish other religions and also as a substitute religion that is approved by God. Ma'had 'Aly quotes verse 58 in QS. al-Māidah (5):

“... walau shā'-Allahu laja'alakum ummataw wahidah, wa lākil liyabluwakum fì mā àtākum..." 
Meaning: “... if Allah willed, you would have been made one person, but Allah wants to test you against the bounty that has been given to you..."

According to Ma'had 'Aly, this diversity is God's will, and he wants to test Muslims with other religions. Mahasantri who also shared their ideas in the TA bulletin, considered that Islam and Christianity had a common ancestor, namely the religion of the Prophet Ibrahim millah in other terms this similarity is called Abrahamism. The TA bulletin also cites one verse 62 in QS al-Baqarah (2) which explains all religions (whether Islam, Judaism, Christianity, Sabi'in) If you do good deeds, then Allah will give you rewards and guarantees of happiness in the. This verse quotes, according to Ma'had 'Aly, that seems to emphasise that all religions are equal in the eyes of God. Even in verse 82 of the QS. al-Māidah (5) explained that the religion closest to Islam is Christianity, and the one most opposed to Islam is Judaism. In short, through this TA bulletin, Ma'had 'Aly students not only destruct traditional fiqh which intentionally does not discuss the relationship between Islam and Christianity but also create a new colour in interpreting the Qur'ān dan Hadith which is considered having not answered the problems of the times.

\section{CONCLUSION}

Based on the research objectives, this article finds that Ma'had 'Aly as a specialised Islamic educational institution (takhașșuș) produces fiqh experts and supports freedom of thought in exploring Islamic law. The reality found confirms that this institution is under the salaf pesantren, but applies the principles of modernity in its implementation, especially in the curriculum and thinking. Ma'had 'Aly offers several solutions that no matter how great a Muslim figure has penetrated, namely closing the door to ijtihād. The curriculum used by Ma'had 'Aly combines classic texts from the yellow book with general books and contemporary books, enabling students to understand the differences and debates that occur in Islamic literature. Unlike the next-door neighbour, Baḥtsul al-Masāil only takes sources from 
classical books. It is the access of students to these two different sources that makes Muslim thinking come out of the romance of dogmatism, Ma'had 'Aly's aim is more on his fiqh methodology than his fiqh product, allowing for wider, free, and in-depth exploration. In Ușūl Fiqh, "nous" has a special position to interpret the Qur'ān and Hadīth, as well as in contextualising the previous laws with the door of ijtihād. From this, it can be seen that Ma'had 'Aly has constructed what is called liberal Islamic thought.

\section{REFERENCES}

Abdullah, W. H. (2020). The contribution of Jalal al-ddin cabd al-rahmanalsuyuti (d: 1445 ad) in the works of sharh Al-hadith: Analysis of six works in Sunan Al-sittah. Journal of Critical Reviews, 7(8), 884-890. https://doi.org/10.31838/jcr.07.08.188

Alamsyah, A. R. (2017). Islamic Post-Traditionalism in Indonesia, written by Rumadi. Asian Journal of Social Science, 45(3), 363-366. https://doi.org/10.1163/15685314-04503007

Arifianto, A. R. (2021). From ideological to political sectarianism: Nahdlatul Ulama, Muhammadiyah, and the state in Indonesia. Religion, State and Society, 49(2), 126-141. https://doi.org/10.1080/09637494.2021.1902247

Aspers, P., \& Corte, U. (2019). What is Qualitative in Qualitative Research. Qualitative Sociology, 42(2), 139-160. https://doi.org/10.1007/s11133-019-9413-7

Bruinessen, M. van. (1995). Kitab kuning, pesantren dan tarekat: Tradisitradisi Islam di Indonesia. Bandung: Mizan, 17.

Dasuki, A. H. (1974). The Pondok-Pesantren: An Account of its Development in Independent Indonesia (1965-73). McGill University.

Dhofier, Z. (1990). Traditional islamic education in the malav archipelago: Its contribution to the integration of the malay world. Indonesia Circle. 
School of Oriental \& African Studies. Newsletter, 19(53), 19-34. https://doi.org/10.1080/03062849008729746

Dhofier, Z. (1994). The Role of Pesantren in the Development of Primary Education in Indonesia. Studia Islamika, 1(2), 47-67. https://doi.org/10.15408/sdi.v1i2.857

Ditpontren Kemenag RI. (2021). Data Pondok Pesantren di Indonesia Tahun 2021. Direktorat Pendidikan Diniyah dan Pondok Pesantren.

Fadli, M. R., Sudrajat, A., Aman, A., \& Amboro, K. (2021). The influence of sorogan method in learning history to increase historical understanding and historical awareness. International Journal of Evaluation and Research in Education (IJERE), 10(1), 300-307. https://doi.org/10.11591/ijere.v10i1.20972

Fauzi, M. L. (2012). Traditional Islam in Javanese Society: The Roles of Kyai and Pesantren in Preserving Islamic Tradition and Negotiating Modernity. JOURNAL OF INDONESIAN ISLAM, 6(1), 125-144. https://doi.org/10.15642/JIIS.2012.6.1.125-144

Hefner, R. (2009). Islamic schools, social movements, and democracy in Indonesia. Making Modern Muslims, Query date: 2021-06-21 06:00:10, 55-105.

Hidayah, S. N. (2021). Pesantren for Middle-Class Muslims in Indonesia (Between Religious Commodification and Pious Neoliberalism). QIJIS (Qudus International Journal of Islamic Studies), 9(1), 209-244. https://doi.org/10.21043/qijis.v9i1.7641

Hikmatulloh, H. (2007). Pesantren dan Ajaran Jihad (Kajian Tentang Internalisasi Doktrin Jihad di Pondok Pesantren Al-Islam Solokuro Lamongan) [Other, University of Muhammadiyah Malang]. https://eprints.umm.ac.id/6700/

Ihsan, I., \& Fatah, A. (2021). Pancasila and Islamic Education: The Deradicalization Model of Madrasahs Based on Islamic Boarding 
Schools in Central Java. QIJIS (Qudus International Journal of Islamic Studies), 9(1), 245-278. https://doi.org/10.21043/qijis.v9i1.8941

Isbah, M. F. (2020a). Pesantren in the changing indonesian context: History and current developments. Qudus International Journal of Islamic Studies, 8(1), 65-106. https://doi.org/10.21043/QIJIS.V8I1.5629

Isbah, M. F. (2020b). Pesantren in the Changing Indonesian Context: History and Current Developments. QIJIS (Qudus International Journal of Islamic Studies), 8(1), 65-106. https://doi.org/10.21043/qijis.v8i1.5629

Ja'far, S. (2013). Pasang Surut Politik Kaum Sarungan. Kanisius. http://repository.uinsby.ac.id/id/eprint/1367/

Lukens-Bull, R. (2019). Pesantren, Madrasa and the Future of Islamic Education in Indonesia. Kawalu: Journal of Local Culture, 6(1), 29-58. https://doi.org/10.32678/kawalu.v6i1.2044

Manshur, F. M. (2020). Typical Literary Works of Pesantren on Righteousness Teaching within Cultural Transformation. Journal of Social Studies Education Research, 11(4), 114-148.

Natow, R. S. (2020). The use of triangulation in qualitative studies employing elite interviews. Qualitative Research, 20(2), 160-173. https://doi.org/10.1177/1468794119830077

Ni'am, S. (2015). Pesantren: The Miniature of Moderate Islam in Indonesia. Indonesian Journal of Islam and Muslim Societies, 5(1), 111-134. https://doi.org/10.18326/ijims.v5i1.111-134

Nurtawab, E. (2019). The Decline of Traditional Learning Methods in Changing Indonesia: Trends of Bandongan-Kitāb Readings in Pesantrens. Studia Islamika, 26(3), 511-541. https://doi.org/10.36712/sdi.v26i3.11026

Raya, M. K. F. (2018). Sejarah Orientasi Pendidikan Islam di Indonesia (Dari Masa Kolonial Hingga Orde Baru). Jurnal Pendidikan Islam, 8(2), 228242. https://doi.org/10.38073/jpi.v8i2.202 
Salminen, A., Kauppinen, K., \& Lehtovaara, M. (1997). Towards a methodology for document analysis. Journal of the American Society for Information Science, 48(7), 644-655. https://doi.org/10.1002/(SICI)1097-4571(199707)48:7<644::AIDASI12>3.0.CO;2-V

van Bruinessen, M. (1990). Kitab Kuning; Books in Arabic Script Used in the Pesantren Milieu. Bijdragen Tot de Taal-, Land- En Volkenkunde / Journal of the Humanities and Social Sciences of Southeast Asia, 146(2), 226-269. https://doi.org/10.1163/22134379-90003218

Zarkasyi, H. F. (2020). Imam Zarkasyi's Modernization of Pesantren in Indonesia (A Case Study of Darussalam Gontor). QIJIS (Qudus International Journal of Islamic Studies), 8(1), 161. https://doi.org/10.21043/qijis.v8i1.5760 